\title{
LITERATURA, CINEMA E MERCADO: \\ UM ESTUDO ACERCA DA TIPOLOGIA DE HERÓIS INSCRITA NA PRODUÇÃO CULTURAL CONTEMPORÂNEA
}

Fernando Teixeira Luiz*

RESUMO: O presente artigo, resultado de uma pesquisa maior em torno dos diferentes perfis de protagonistas que povoam tanto a literatura quanto o cinema, ocupa-se em mapear os modelos de heróis que transitam pela produção cultural contemporânea dirigida ao público jovem. Para tanto, toma-se como referência as contribuições teóricas de Campbel (2007) e de críticos que se voltam às articulações entre literatura, cinema e indústria cultural. Logo, este artigo não tem a pretensão de analisar uma ou outra obra, mas rastrear, a partir de um olhar historicista e do percurso das personagens protagonistas em diferentes textos e contextos, as múltiplas faces do herói contemporâneo frente aos diversos interesses de mercado.

PALAVRAS-CHAVE: Cinema; Herói; Literatura.

\section{Introdução}

Gotlib (2000), abordando a matéria literária a partir de uma perspectiva estruturalista, salienta que as personagens podem ser agrupadas com base no papel que desempenham no enredo. Nesse sentido, se dividiriam, basicamente, entre protagonistas e antagonistas. As protagonistas são aquelas que possuem traços superiores ao seu grupo, ao passo que as antagonistas são marcadas pela oposição para com a figura do herói. Campbell (2007), vol-

\footnotetext{
* Doutor em Letras (Leitura, Crítica e História Literária) pela Universidade Estadual Paulista Júlio de Mesquita Filho (Unesp). Professor da Universidade do Oeste Paulista (Unoeste).
} 
tando-se ao acervo lendário universal, reconhece a presença de variados tipos de protagonistas, que constituem desdobramentos do herói primordial, cabendo aqui citar o herói guerreiro, o herói amante, o herói santo e o herói imperador. Embora tais desdobramentos sejam importantes, sublinhamos a atuação do herói primordial, em princípio fabuloso e grandiloquente, cedendo espaço, pouco a pouco, a um ciclo de protagonistas cada vez mais humanos, dotados de determinados poderes e responsáveis por grandes prodígios. Partindo desses pressupostos, pretende-se, nessa unidade, rastrear, catalogar e discutir um conjunto de heróis que migraram da mitologia, do folclore e da literatura clássica para a produção contemporânea endereçada aos jovens, integrando a literatura, o cinema e as animações.

\section{1- O herói modelar}

O herói modelar está presente na mitologia pagã e nas novelas de cavalaria, sendo posteriormente recuperado no cinema em meio a diversas adaptações. É o herói leal, virtuoso, intrépido e altaneiro, representante de uma coletividade, desdobrando-se nas imagens de Hércules, Teseu, Ulisses, Jasão, Belerofonte e outros ilustres guerreiros. São homens que, incumbidos de árduas missões e em meio a longas jornadas, colocam a própria vida em risco, enfrentando hidras, quimeras e ciclopes. Para melhor detalhar tal tipo de protagonista, tomemos como exemplo a figura emblemática de Perseu e as diversas releituras de seu mito propostas pela sétima arte.

No texto clássico ${ }^{1}$, o nascimento de Perseu estaria em plena articulação com uma profecia anunciada pelo oráculo: o intrépido rapaz haveria de matar o avô. Na época, o rei Acrísio, ao tomar conhecimento do presságio, ordenou para que trancassem a filha Dânae em uma câmara de bronze subterrânea. Acontece que Zeus, o senhor do Olimpo, seduziu a garota. Acrísio, não acreditando que a filha estivesse grávida do temido deus, a aprisionou em uma arca, lançando-a mar adentro.

1 Estamos nos valendo da compilação de Thomas Bulfinch, O livro de Ouro da Mitologia (2006), veiculado pela Ediouro. 
Na primeira adaptação do mito de Perseu para o cinema, que não é de 2010 e sim de 1981, a descrita cena se repete. Porém, há aqui a desforra de Zeus: irritado com a atitude de Acrísio, ele liberta o titã Kraken ${ }^{2}$ para que punisse a cidade de Argos com o total derramamento de sangue. A adaptação de 2010 parece mais pautada na adaptação de 1981 do que no próprio mito. O Kraken é aqui mantido e apresentado para o telespectador como uma criatura nascida da própria carne de Hades. O rei Acrísio, em contrapartida, é condenado pelo crime contra Dânae e transformado, desse modo, em um mutante denominado Calibos. No roteiro anterior, de 1981, Calibos é filho de Tetis, a deusa dos mares. Tratavase de um jovem prepotente que se casaria com a princesa Andrômeda e que, em razão de sua índole, foi transformado por Zeus em um demônio. Tanto no roteiro de 1981 quanto no de 2010, Calibos se torna o principal antagonista de Perseu, o que não acontece na narrativa grega. Lá, os duelos se concentram entre o semideus e o rei Polidectes - ancião que, por sinal, andava apaixonado pela mãe do rival - fato que acabou gerando diversos conflitos entre os dois guerreiros.

Quanto ao violento combate entre Perseu e Medusa, convém ressaltar que se trata de uma cena presente já na mitologia e que vai receber novos contornos nas posteriores adaptações. No mito, a busca pela górgona devia-se a um torneio em que o vencedor seria quem trouxesse a cabeça da horrenda criatura ao rei Polidectes. Na verdade, era uma estratégia do monarca para se livrar de Perseu, visto que avaliava o semideus como uma possível ameaça na consumação de seu amor por Dânae. Nas releituras de 1981 e 2010, a procura pelo monstro se justificava como a única forma de salvar Andrômeda do gigantesco Kraken e dos caprichos impostos pelos vingativos deuses (Tetis e Hades).

Para concluir essas reflexões, caberia ainda um parágrafo a fim de reiterar como Perseu - o grande protagonista - foi representado nas duas versões do mito. E aqui vale

\footnotetext{
${ }^{2} \mathrm{Na}$ verdade, o Kraken - criatura marítima cheia de tentáculos - nem faz parte da mitologia grega, e sim da nórdica.
} 
lembrar que o princípio do herói clássico (verdadeiro, justo, pleno de bravura e representante de uma coletividade) foi preservado nas releituras cinematográficas da narrativa. Perseu, como explica o mito, salvará a mãe das investidas dos inimigos e, nas recriações de 1981 e 2010, lutará contra escorpiões gigantes, enfrentará sorrateiros demônios e desafiará os titãs do Tártaro para impedir a destruição da cidade de Joppa (no filme de 1981) ou de Argos (na produção de 2010). O cinema, contudo, faria com que a epopeia do filho de Zeus não terminasse aqui. Em 2012, para possibilitar a franquia, foi criada uma nova façanha envolvendo o herói. O problema é que a fórmula empregada foi exatamente a mesma do primeiro filme, incorporando novos monstros que reportavam às histórias de Cronos, Teseu, Belerofonte e outras personagens registradas pelo poeta Hesíodo. Além disso, fica nítido na tela o fértil diálogo que o filme manteve com a linguagem das histórias em quadrinhos, dos desenhos animados e de outras produções do gênero, como as sequências de ação coreografadas, em câmara lenta, que lembram Matrix (1999), ou os incríveis enquadramentos, plenos de grandeza épica, próprias de Conan (1982) ou Simbá (1977).

Na mesma linha de Perseu, outros heróis modelares, agora oriundos dos cartuns, migrariam para o cinema e emplacariam memoráveis sucessos de bilheteria. A esse respeito, convém citar, nos anos 70 e 80, a saga de dezenas de protagonistas que coadunavam a ideologia de supremacia norte-americana, como acontece com o patriota Superman (1978). Outros, embora não tivessem suas raízes nas HQs, preservavam tal ideologia nas nuances de seus respectivos roteiros, como, no caso, John Rambo, de 1982, e os Caça-fantasmas, de 1984.

No que tange aos Caça-Fantasmas, temos um quarteto de figuras masculinas (Peter Venkman, Egon Spengler, Ray Stantz e Winston Zeddmore) que deve salvar Manhattan de um gigantesco monstro de marshmallow. Para tanto, são aclamados pelos cidadãos novaiorquinos como única esperança de preservar a nação norte-americana do quadro apocalíptico. O sucesso do filme, escrito por Harold Ramis e Dan Aykroyd, rendeu duas indicações ao Oscar e uma série animada bastante popular, que vigorou de 1986 a 1991. Rambo, por sua vez, outrossim transitaria do cinema para as animações. O herói integraria a "Força 
da Liberdade”, um grupo especial de agentes norte-americanos empenhados na luta contra as organizações terroristas. Morelli (2010), a esse respeito, salienta que "a série durou apenas uma temporada e recebeu duras críticas da imprensa, por adaptar um personagem tão violento para um desenho animado” (p.114). Assim, Rambo, mesmo estando em contexto que pouco priorizava a ideologia nacionalista, apresentaria um discurso ainda bastante ufanista, enaltecendo a própria pátria e sublinhando a supremacia dos Estados Unidos da América.

Sublinhamos ainda presença de heróis modelares no campo da ficção científica. Os roteiros desse grupo, embora preservassem o tom épico do roteiro, deixavam, na maioria das vezes, transparecer um traço bastante particular: a mistura de temáticas medievais a ambientes futuristas. É o que acontece, por exemplo, em Mestres do Universo (1987), com He-Man, e na trilogia Guerra nas Estrelas (1977, 1980, 1983), com Luke Skywalker.

Finalmente, chegamos ao cinema contemporâneo. A análise dos novos títulos que se inserem no mercado atesta a nitidez com que diretores e roteiristas ainda abordam protagonistas filiados à linhagem de Perseu. É o que acontece, por exemplo, com Aragon $(O$ Senhor dos Anéis (2001)), Aslam (Crônicas de Nárnia (2005)), Harry Potter (Harry Potter e a Pedra Filosofal (2001)) e, sobretudo, Pierce Jackson (Pierce Jackson e os Olimpianos (2010)). Em linhas gerais, parte significativa dos filmes até aqui mencionados constituem releituras, adaptações e atualizações de diversos sistemas mitológicos ${ }^{3}$, orientados por propostas não tão nacionalistas ${ }^{4}$ como as que embalaram os anos de 1970 e 1980. Aliás, a opção pelo

\footnotetext{
${ }^{3}$ Não estamos nos referindo apenas à mitologia greco-romana, mas também à nórdica e à hindu, cujos ecos se fazem presentes em parte expressiva da produção juvenil de Hollywood.

${ }^{4}$ Convém sublinhar que mesmo a adaptação das histórias em quadrinhos essencialmente nacionalistas das décadas anteriores, sofre aqui nítidas reformulações. Tal dado pode ser reiterado na análise de lançamentos como Capitão América (2011), Lanterna Verde (2011) e O Espetacular Homem Aranha (2012), em que a ideologia ufanista cede espaço a uma aventura em que a afirmação e reafirmação do instinto de nacionalismo norte-americano não é o principal aspecto a ser apurado.

Não estamos afirmando que o sentimentalismo patriótico inexista nessas produções. O que queremos ressaltar é que tal sentimentalismo encontra-se bastante atenuado, diluído, se comparado ao que se produziu nas primeiras décadas do pós-guerra, quando os Estados Unidos recorriam à sua galeria de heróis para disseminar a ideia de supremacia perante as outras nações (cf. ECO, 1964). A própria composição cromática das indumentárias dos protagonistas corroborava essa informação, fazendo alusão às cores da bandeira norte-americana.
} 
épico parece ser muito recorrente na literatura contemporânea e na produção cinematográfica que se firmaria no século XXI. Na trilogia de Tolkien, a formação e o rompimento da sociedade do anel, em meio às peripécias de Frodo e Gollun, servirão de base para detalhar a sangrenta batalha entre hobbits, elfos e feiticeiros perante os exércitos inimigos liderados por Sauron. Batalha que igualmente se repetiria nas terras de Nárnia, envolvendo crianças e adolescentes em um universo pleno de alusões bíblicas e, paralelamente, povoado por centauros, minotauros, faunos e animais falantes. $\mathrm{O}$ ambiente bélico também envolveria a escola de Hogwarts, materializando-se nos últimos confrontos entre Harry Potter e Lord Voldemort. A presença da temática da guerra, atrelada às referências intertextuais da cultura greco-romana, ganharia ainda mais força na saga de Peirce Jackson. Aqui, a mitologia é devidamente atualizada e os deuses do Olimpo migram para o espaço urbano. Embora Jackson esteja na condição de semideus, sua essência dialoga com o perfil de adolescentes contemporâneos, possibilitando e assegurando o processo de identificação por parte do leitor: o protagonista integra um típico meio social de classe média e guarda problemas familiares com a figura paterna.

O tom épico inscrito na caracterização das aventuras dos olimpianos, bem como no mundo de Aslan, na escola de Hogwarts e na Terra Média, misturando elementos do panteão grego à mitologia nórdica e cristã, consiste um dado a ser averiguado em outros títulos da literatura que se impõe no atual contexto histórico. É o que sugere um conjunto de narrativas filiadas a essa linhagem, como, por exemplo, A Batalha do Apocalipse (2010), de Eduardo Spohr, A Maldição do Tigre (2011), de Colleen Houck, Rei do Inverno (2011), de Bernard Cornwell e A Ordem (2012), de Nate Kenejon, bem como nas séries Crônicas de Gelo e Fogo (1996), de George Martin e Assassins Creed (2011), de Oliver Bowden. Parecem todas herdeiras da proposta instaurada na literatura de Tolkien, Riordan, Rolling e C. S. Lewis, que abordam grandes feitos a partir da releitura, réplica e atualização de signos e personagens de diferentes sistemas semióticos e campos narrativos (a lenda, a mitologia, a religião, a história, os games e as novelas de cavalaria). 


\section{2 - Avatares do herói modelar: o amante, o vingador e o santo.}

Segundo Campbell (2007), o herói amante é tributário do herói modelar primordial. No entanto, diferencia-se do mesmo por não ser um redentor da humanidade. Sua missão está em salvar a mulher amada dos sorrateiros perigos, dos sortilégios e armadilhas representadas por meio de ogros, feiticeiros e dragões. O herói amante está na lenda de Tristão e Isolda e perambula pelos contos de fadas, materializando-se em personagens masculinas que se sacrificaram em nome da donzela virgem, aprisionada na torre inexpugnável. Nesse sentido, a animação intitulada A pequena sereia $(1989)^{5}$, veiculada pelos estúdios Disney e inspirada no conto de Hans Christian Andersen, agrega um típico exemplo dessa categoria de herói: o príncipe Érik, que se arriscaria para salvar a jovem Ariel dos imponentes perigos que se escondem nas profundezas dos oceanos. A saga do príncipe é, sobretudo, a saga de um cavaleiro errante em busca da cortejada mulher, cercados por uma série de obstáculos insólitos.

O mesmo acontece em outros contos de fadas ${ }^{6}$, como Rapunzel (1812), em que o astucioso amante é movido pelos encontros secretos com a donzela de longos cabelos, ou A Bela Adormecida (1812), em que o jovem varão tem o dever de desafiar a décima terceira fada a fim de salvar a princesa de uma tortuosa maldição. Em todas essas narrativas exaltase a subordinação e a fragilidade feminina, típicas do universo dos contos populares do século XVII. As mulheres, aqui, ainda são incapazes de administrar e resolver os próprios conflitos, e por isso sempre recorrem à figura masculina, personificada como um nobre e notável cavaleiro - homem branco, robusto, valente, europeu, heterossexual e de elevada estirpe.

A releitura contemporânea dos contos de fadas, embora delineasse uma donzela não mais tão dependente, privilegiaria um herói com os mesmos traços do nobre varão,

\footnotetext{
${ }^{5} \mathrm{O}$ ano apresentado, 1989, refere-se à estreia da animação. Já o conto, assinado por Andersen, reporta ao século XIX.

${ }^{6}$ Estamos nos referindo a outras obras fora do eixo dinamarquês, rubricadas por Charles Perrault e, posteriormente, resgatadas pelos irmãos Grimm.
} 
ainda que não pertencesse ao universo palaciano. Para compreender essa questão, tomemos como referência o filme Branca de Neve e o Caçador. Lançado em 2012, o longa-metragem alteraria alguns elementos do enredo clássico: a princesa perderia sua inocência, a rainha enlouqueceria com a obsessão de se manter jovem e, no outro pólo, novos personagens seriam incorporados à trama. O grande destaque estaria na atuação do caçador, que, muito mais que o príncipe, dedicaria sua vida a Branca de Neve, preparando-a para a luta em meio às adversidades da floresta negra. O vínculo entre ambos torna-se tão forte que, ao desfecho, não é o afeto do príncipe que despertará a garota da maldição, mas sim o beïo do caçador. O beijo, que reporta às narrativas tradicionais europeias, funciona igualmente como signo. Segundo Lurker (2003), subjaz aqui a ideia de transmissão de forças por meio do sopro. O beijo é expressão de entrega espiritual, configurando a amizade, o amor e, sobretudo, a veneração.

A rigor, a literatura juvenil contemporânea emplacaria com uma série de protagonistas tributários do novo perfil amante. Um dos mais emblemáticos, nessa linha, estaria não na figura de um príncipe, mas de uma criatura que a cultura popular, de conduta cristã, rotulou como luciférica. Estamos nos referindo a Edward Cullen, o vampiro da série Crepúsculo. Lançado em 2005 e adaptado para as grandes telas em 2009, 2010, 2011 e 2012, o texto de Stephanie Mayer trataria da relação de amor e conflito entre a jovem Isabelle Swan e seu amado. Relação essa regada e salpicada por desejo e mistério, em que a presença da garota incitaria em Edward o anseio de provar seu sangue. Lutando contra os próprios instintos, o vampiro se entregará à paixão e acabará salvando a jovem de uma série de ameaças. A narrativa, por sua vez, recupera, acata e reproduz uma fórmula bastante convencional entre adolescentes: a recriação de uma história já decodificada entre jovens leitores (o amor proibido), ou, na expressão de Eco (1991), um estilo réplica, uma estrutura que se dirige ao encontro do que o leitor identifica, reconbece e almeja. Possivelmente isso justifique o expressivo sucesso da série tanto na literatura quanto em sua projeção no espaço da sétima arte. A equação estabelecida entre a virgem e a aterradora figura masculina - objeto de temor e prazer - já havia sido empregada em outros títulos anteriores, como, por exemplo, 
nos romances A Bela e a Fera (1740) e Drácula (1897), desdobrando-se, no cinema, em Nosferatu (1922) e, posteriormente, em A Mosca (1986).

O herói vingador, diferente do amante, dedica-se não em salvar um ente querido, mas em aniquilar aquele que outrora lhe fez mal. Seu ascendente se encontra no herói modelar, precisamente em Ulisses e Telêmaco, que arquitetaram um plano de represália endereçado aos pretendentes de Penélope. O cinema, não obstante, explorou inúmeros tipos humanos inscritos nessa categoria, como Maximus, o gladiador, e Batman ${ }^{7}$, o cavaleiro das trevas. Em Sleepers (1998), a discussão ganha polêmicos contornos e subverte as convenções éticas. Em razão de uma brincadeira inconsequente, quatro garotos são condenados e enviados a um reformatório. Ali, submetidos às sessões de tortura e sequências de abuso, eles padecem em meio às loucuras dos sádicos guardas. Nesse ambiente hostil, conhecem a literatura libertadora de Alexandre Dumas: O Conde de Monte Cristo (1844) - romance que lhes aliviará a dor e alimentará, gradativamente, a obsessão pela posterior desforra.

Com César, o chimpanzé que protagoniza o novo título da franquia O Planeta dos Macacos $(2011)^{8}$, a proposta não seria diferente. Ele se encontraria em posição similar a dos outros vingadores aqui tratados, sendo, muitas vezes, confundido com um anti-herói ${ }^{\text {. A }}$ rigor, diferenciar-se-ia de tal tipologia de personagem por não apresentar nenhum desvio de caráter. Todavia, recorre a meios pouco lícitos para instaurar a justiça, manipulando coadjuvantes, provocando acidentes e instituindo a revolução. Os caminhos direcionados pelo roteiro recuperam a história do herói - do momento em que foi acolhido pelo cientista San até as humilhações no centro de controle de animais - o que justifica, para o público, sua revolta e a posterior retaliação.

\footnotetext{
7 Adaptação dos quadrinhos e da série animada.

${ }^{8}$ Embora a refilmagem de Tim Burton, em 2001, não alcance a popularidade da série de 1968, a nova produção de 2011 (inspirada, precisamente, em A Conquista do Planeta dos Macacos (1972)) consegue manter a verve impactante e aterradora do clássico dirigido por Franklin Schaffneo, baseado no romance de Pierre Boulle.
}

${ }^{9} \mathrm{O}$ conceito de anti-herói será aplicado e esclarecido um pouco mais adiante. 
Atento ao problema e igualmente indignado com a situação do chimpanzé, o leitor - na condição de co-autor do filme - se mostrará solidário à causa do personagem. Acompanhará, dessa forma, todo o percurso de ascensão dos símios e a derrocada da raça humana, rumo à consolidação e legitimação do planeta dos macacos.

Para entender melhor o papel exercido pelo leitor frente à dinâmica da escritura artística, convém retomarmos algumas observações da teoria literária. Ferreira (2009), partindo do pressuposto de que o leitor é co-autor do texto, sublinha a relação dialógica entre a obra e o leitor. Essa relação decorre da estrutura do discurso, ou seja, da presença de hiatos, lacunas e vazios que solicitam do leitor um importante papel na composição artística: o de organizador, revitalizador e cúmplice do pacto proposto pelo filme. Tal pacto só pode ser executado quando o leitor preenche todos os pontos de indeterminação do texto por meio das inferências, acatando ou não o que lhe foi sugerido. Nesse caso, a obra solicita para que o destinatário se sensibilize com todo o percurso de dor e humilhação de César, mesmo que isso signifique e repercuta na ruína da raça humana. Em suma, as narrativas desse porte carregam algumas características similares: o protagonista surge em uma situação confortável, surpreendido, a seguir, por inúmeros infortúnios que abalam seu estado inicial e o conduzem à absoluta derrota. Consciente do ocorrido, tal personagem tem a oportunidade de reconstruir a própria história e punir aqueles que outrora lhe fizeram mal. Para tanto, recorre a uma particular moral em que os fins justificam os meios.

O herói santo, diferente dos demais, configura-se como outro tipo de protagonista pertencente à linhagem de heróis primordiais. Campbell (2007) o define como aquele que "renuncia o mundo" (p.337), surgindo nas narrativas quase sempre na condição de semideus. Na literatura cristã e nas produções cinematográficas (de orientação religiosa ou não), o herói santo se apresenta mediante nomes insignes da tradição ocidental: a atuação de profetas, apóstolos e toda a trajetória de Jesus Cristo. No entanto, convém salientar que há incidência desse tipo de herói em outros panteões, como, por exemplo, acontece nas narrativas que envolvem o Buda. O importante aqui a ser frisado reside na mensagem humanista que é propagada por essas personagens. São protagonistas que substituem a espada - 
arma até então utilizada pelos heróis que os precedem - pela palavra, pelo discurso, pela capacidade de dissuadir o outro por meio de parábolas direcionadas ao respeito e à tolerância.

\section{3 - O herói ingênuo}

Umberto Eco (1985), ao discorrer sobre o romance O Nome da Rosa (1984), chama a atenção para uma intrigante personagem: o jovem Adso de Melk. Trata-se de um protagonista alheio aos fatos e que, como o leitor, pouco a pouco desvenda a sutil teia de mistérios que envolvem a abadia. Há, assim, uma identificação muito grande do destinatário para com o citado rapaz. Ambos se encontram perdidos em um complexo labirinto e precisam decifrar, compreender e organizar as incógnitas que pairam na biblioteca. Em outras palavras, estamos falando do herói ingênuo, que, na mesma proporção do leitor, lentamente descobre a rede de intrigas em que está inserido.

Adso foi muito importante para mim. Desde o início eu queria contar toda a história (com seus mistérios, eventos políticos e teológicos, ambigüidades) com a voz de alguém que atravessa os acontecimentos, registra todos eles com a fidelidade fotográfica de um adolescente, mas não os compreende (e não os compreenderá nem mesmo quando velho, tanto que depois escolhe uma fuga para o nada divino que não era a que lhe ensinara seu mestre). Fazer compreender tudo através das palavras de alguém que não compreende nada.

Lendo as críticas, noto que este é um dos aspectos do romance que menos impressionou os leitores cultos, ou pelo menos eu diria que quase ninguém o destacou. Mas agora me pergunto se este não foi um dos elementos que determinaram a legibilidade do romance por parte de leitores não sofisticados. Identificaram-se com a inocência do narrador, e sentiram-se justificados mesmo quando não compreendiam isso. Devolvithes seus tremores diante do sexo, das linguas desconbecidas, das dificuldades do pensamento, dos mistérios da vida política... (ECO, 1985, p. 32, grifos nossos)

Geralmente, as narrativas que envolvem o herói ingênuo contam com segredos milenares a serem desvendados (como acontece no filme O Código da Vinci [2006]), crenças e tabus jamais questionados (A Vila [2004]) ou tragédias ainda incompreendidas pelo protagonista (O Menino do Pijama Listrado [2008]). Nesse emaranhado, cumpre sublinhar que um 
evidente traço desse tipo de personagem está em sua postura insegura, titubeando entre certezas e dúvidas acerca da própria trama em que está inserido.

Valérie, a jovem que integra o romance A Garota da Capa Vermelha (2011), outrossim reporta a esse perfil de protagonista. O enredo, dialogando com o conto Chapeuzinho Vermelho (1812), recorre igualmente ao signo escarlate, delimitado, na tabela cromática, como referência à libido e à proteção contra as entidades demoníacas (LURKER, 2003, p. 747). No entanto, mesmo recorrendo às homologias sígnicas, a história se justifica, por meio da metalinguagem, como uma lenda, cuja estrutura acabou sendo alterada pelo tempo e pelas convenções. Na versão apresentada, extraída do relato da própria heroína, o lobo mau, típico do famoso conto atrelado aos nomes de Charles Perrault e dos irmãos Jacob e Wilhelm Grimm, é substituído por um gigantesco lobisomem que aterrorizava a aldeia de Daggorhorn, espalhando pânico, estragos e mortes. A explicação para o massacre não demoraria a surgir: o monstro pretendia dizimar todo o povoado, a não ser que a bela Valérie concordasse em acompanhá-lo. Instaura-se, então, um nítido dilema na trajetória da garota, que corresponderia, praticamente, ao plot que moveria toda a trama: quem, na verdade, seria o lobisomem? O que, afinal, ele almejava? Por que tanto apetecia a garota da capa vermelha?

Tais questões acompanhariam Valérie, em sua solitária toada, por toda a narrativa. O leitor, solidário aos conflitos da personagem, dividirá com ela parte das angústias e compartilhará das mesmas suspeitas perante a identidade secreta da fera, atribuindo-a, em princípio, a Peter, o homem que amara desde a infância. É o início, então, de um envolvente thriller, em que os signos do conto de fadas passariam pelo processo de ressignificação e as pistas para a resolução do mistério seriam descobertas pela donzela e, simultaneamente, pelo leitor. Assim, ambos, alheios às incógnitas que rondam o enredo, chegariam, juntos, à resolução do enigma.

O longa Alice no País das Maravilhas (2010), na releitura que Tim Burton faz do clássico de Lewis Carroll, introduz uma heroína ingênua em uma nova roupagem: ao contrário do leitor, pleno de convicções de que a jovem Alice já esteve, em seu passado, no mundo 
subterrâneo, é apenas a protagonista que se sente cheia de dúvidas com relação à veracidade desse fato. Á medida que a narrativa ganha força, Alice, pouco a pouco, conscientiza-se em torno de sua identidade, até o ponto de perceber que não estava sonhando e que seu destino era matar o Jaguardarte - missão que se mostrava, no primeiro momento, inexequível. A cena de confronto entre a heroína e o monstro, pautada em uma fotografia revestida de cores escuras e tons cinzas - repercutindo, assim, em uma cadeia sígnica que reporta à transitoriedade da vida, que permeia luto, penitência e purificação (LURKER, 2003, p. 138) - conduz o leitor à adaptação da Disney de A Bela Adormecida (1959), no ensejo em que o príncipe Felipe, no topo das velhas ruínas, enfrenta a feiticeira Malévola, aqui materializada na imagem aterradora de um dragão. Tanto em Alice no País das Maravilhas quanto em $A$ Bela Adormecida, edifica-se um ambiente soturno, reportando à estética medieval. Estética essa reconstruída por meio de elementos que fazem parte do universo dos nobres cavaleiros (como o escudo e a espada), e de figuras que povoavam o imaginário coletivo (as bestas).

Cumprida a missão de matar o Jaguardarte, Alice se emancipa e, libertando-se das convenções sociais, inicia um novo percurso em que reafirma a própria identidade. Assim, opta por assumir que apreciava coelhos (contrariando a voz dos adultos, que rejeitavam o animal) e decide acabar com o noivado a contragosto. Desse modo, subvertendo a proposta das narrativas tradicionais, que encontram no matrimônio a única possibilidade de alcançar a felicidade, a heroína aqui prefere se manter solteira e, na condição de aprendiz, dedicarse exclusivamente ao trabalho.

\section{4 - O herói excêntrico}

O limiar do século XXI introduz um conjunto de produções com anseios que destoariam das grandes sagas até então norteadas por protagonistas primordiais (modelares, amantes e vingadores). Em plena sintonia com o que Hutcheon (1991) destacaria como poética da pós-modernidade, e em articulação com as vertentes mais recentes da literatura para crianças e jovens, o cinema e a animação desse contexto abrem espaço para a paródia, a 
intertextualidade, a metaficção, a plurissignificação e, sobretudo, a incorporação de figuras excêntricas (HUTCHEON, 1991), até o momento destituídas de vez e voz, como as crianças, as mulheres, os homossexuais e as diferentes etnias que estão à margem do eixo europeu.

Hutcheon (1991), debruçando-se sobre a pós-modernidade, chama a atenção para a crítica à centralização da cultura perante o local e o periférico. Nessa proporção, assinalarse-ia o discurso definido por diferenças de classe, raça, sexo, identidade étnica e status pátrio. A retórica betero, euro e etnocêntrica foi desafiada, ao passo que o excêntrico - refestelando-se em várias manifestações artísticas - rompe com a hierarquia imposta pela tradição cultural. Shrek ${ }^{10}$, por exemplo, opõe-se à tradição das clássicas narrativas infantis, uma vez que, na condição de protagonista, não se conceitua como um príncipe europeu, branco, altaneiro e herdeiro de um cobiçado trono, mas sim como um ogro verde e gordo. Com a família Hoover, em Pequena Miss Sunshine (2006), a crítica à epopeia do vencedor se encontra em primeiro plano. Os heróis modelares, vingadores e amantes cedem lugar a heróis cada vez mais excêntricos. Aqui, o pai, Richard, embora incorpore o discurso do vitorioso, não passa de um grande fracassado. O tio, Frank, é um homossexual que acaba de ser abandonado pelo namorado e jamais emplacou como o maior especialista em Proust. O avô, expulso de um asilo, é despojado e se distancia do convencional modelo de idoso meigo e fraterno. Olive, a menina aspirante a miss, usa um enorme par de óculos e exibe uma pança assaz saliente. São figuras marginais, bastante próximas do leitor, e que não tem a menor pretensão de se firmar como suntuosas personagens. Ao contrário, abrem espaço para a diversidade de tipos humanos e suas múltiplas fraquezas. Pequena Miss Sunshine, nesse sentido, não se debruça sobre nenhum itinerário de triunfo e glória, mas no cotidiano de lutas e privações de uma família simples, composta, basicamente, por uma menina, um velho, um suicida, um daltônico, uma divorciada e um vendedor de autoajuda.

${ }^{10}$ Estamos nos referindo ao longa-metragem lançado em 2000. 
Em última análise, Frankenweenie ${ }^{11}$ (2012), dos estúdios Disney, introduz protagonistas ainda mais alternativos. A animação em stop-motion, embora se revele pouco imprevisível, é bastante sensível, impondo-se em um contexto praticamente dominado pela Dream Works. Para tanto, vale-se de uma narrativa que intercala referências intertextuais ${ }^{12}$ da história do cinema, em especial do gênero terror. Assim, desfilam, perante os olhos do leitor, personagens que fazem alusão a Frankenstein (1931), O Corcunda de Notredame (1939) e Godzila (1954). Para recriar o ambiente sombrio do cinema clássico, o diretor, Tim Burton, optou por manter a animação em preto e branco. A estratégia obtém êxito, e o longametragem lembra, com sucesso, títulos do início do século como Vampiros (1915), Nosferatu (1922), O Fantasma da Ópera (1925) e Drácula (1931). As personagens, em harmonia com esse universo, apresentam leve palidez e olhar inexpressivo. Consequentemente, o entrecruzamento desses elementos torna ainda mais significativa a temática tratada ao longo do enredo: a morte.

A esse respeito, é patente na produção juvenil contemporânea a discussão em torno de questões polêmicas antes restritas ao mundo adulto, como a violência, o divórcio e, no caso supracitado, o óbito. Lajolo e Zilberman (1988) já haviam problematizado tal ponto no processo de formação e consolidação da literatura para adolescentes, em especial na obra de Lygia Bojunga. Com as animações não seria diferente, e Frankenweenie se debruça, a partir do drama vivenciado pelo garoto Victor, sobre toda a dor e angústia decorrente da morte de seu cachorro de estimação.

Cabisbaixo e impaciente, o menino, influenciado pelas aulas de Ciências, não hesita em agir: desafia as leis da natureza em nome de seu amor incondicional. Nessa direção, Lotterman (2010, p.26) sublinha que é patente, na produção cultural, a representação da morte de animais de estimação. No universo ficcional, o luto perante a ausência de tais

\footnotetext{
11 Remake da produção de 1984.

${ }^{12}$ As referências intertextuais se projetam até mesmo no título da narrativa, sugerindo o famoso romance de Mary Shelley, Frankenstein.
} 
animais acaba gerando tensão e, por conseguinte, revolta entre as personagens que os perderam. Em alguns casos, os garotos, na ausência de seus mascotes, adoecem, podendo, inclusive, falecer em decorrência do sofrimento. Ademais, as citações de Frankenstein em Frankenweenie são frequentes. Exemplo disso é a relação entre o pequeno Victor e o desengonçado Edgar, que reporta o leitor, de imediato, às cenas entre o Dr. Henry Frankenstein e o corcunda Fritz. A alusão a Frankenstein também se projeta no ensejo de ressurreição do cachorro Sparky, quando ele é erguido, em uma mesa de operação, em direção ao céu pleno de relâmpagos e trovões; ou ainda quando o cãozinho é perseguido por um conjunto de cidadãos empunhando tochas reluzentes. É como se a narrativa não apenas parodiasse, mas, sobretudo, homenageasse os clássicos de terror, solicitando a atenção dos destinatários para os pioneiros do gênero.

$\mathrm{Na}$ esteira de propostas dessa ordem, outras produções também recorreriam a heróis excêntricos e tematizariam tudo o que o sistema cultural europeu relegou a segundo plano: o exótico, o bizarro, o infame, a favela, a prostituição, os guetos, o submundo e a malandragem.

\section{5 - O anti-herói}

Sabe-se que as protagonistas excêntricas não se qualificam como modelos de virtude. Pica-pau, por sua vez, dirigiria essa proposta aos extremos, estabilizando-se como um anti-herói. Gotlib (2000) define o anti-herói como aquele que se encontra na condição de protagonista, mas sem mérito para tanto. A rigor, trata-se do herói sem caráter, movido pelos próprios interesses e orientado pela conduta individualista. Ainda assim, é capaz de seduzir o leitor, conquistando seu consentimento em meio a inúmeras patranhas. Diferente das personagens tratadas nos itens anteriores - bastante contemporâneas - Pica-pau tem suas aventuras e desventuras produzidas entre 1940 e 1972, época em que os desenhos se preocupavam em propagar determinada mensagem educativa. Nessa linha, enquanto os heróis clássicos revelavam uma coerência na defesa de valores como justiça, honra e leal- 
dade, o Pica-pau construía uma coerência particular, movida pelos próprios interesses. Assim, o pássaro, destituído de qualquer pudor, não hesitaria em enganar, mentir ou roubar. Em harmonia com essas constatações, Pacheco (1985) assinala que as práticas do Pica-pau não estão a serviço do bem coletivo, mas, ao contrário, ressaltam a individualidade. A sua força se encontraria na esperteza, na malícia, na malandragem, e não em utensílios mágicos como os respeitados cavaleiros da literatura que o precede. Ele quase sempre vence o adversário recorrendo a artifícios pouco lícitos, e, ainda assim, conquista a adesão, aprovação e empatia do leitor.

Na mesma linha do Pica-pau, as animações explorariam uma legião de personagens solidários a tal perfil. Frente a isso, é oportuno assinalar os episódios ${ }^{13}$ estrelados por Pernalonga, Patolino, Manda-Chuva, Zé Carioca e, em especial, O Gato de Botas. Migrando da literatura para as animações, O Gato de Botas (2012) é um típico exemplo de uma narrativa centrada na veiculação de um herói destituído de caráter. O sucesso emplaca em Shrek II (2003), integrando a trupe do austero ogro na condição de versátil espadachim. Nessa linha, o gato, com base na dicotomia entre essência e aparência, apresenta-se como um frágil felino que, na verdade, era um destemido guerreiro.

O sucesso da personagem permite a Drean Works a projeção de um novo título protagonizado pelo bichano. Assim, em 2012, foi lançado o longa-metragem O Gato de Botas. A produção mantém a fórmula empregada em Shrek, pautada, basicamente, na intertextualidade. Revelam-se, desse modo, referências a outros textos, como Zorro, Batman, Alice no País das Maravilhas e João e o Pé de Feijão, entre outros. O tempo a ser narrado é bastante preciso: tudo acontece anos antes do gato conhecer Shrek e a princesa Fiona. O maior problema, contudo, está no hiato que separa o desenho da Drean Works do clássico infantil rubricado por Basile, Perrault e Jacob e Wilhelm Grimm. Consequentemente, na efabulação apresentada não há nenhuma alusão aos elementos que compõe o conto na versão dos escritores europeus. Em outras palavras, a animação não pretende recuperar ao

${ }^{13}$ Estamos nos referindo tanto a produções curtas, veiculadas em séries, quanto ao cinema de animação. 
leitor todo o percurso do felino rumo a consagração de seu amo. Ao contrário disso, uma outra história é contada, contrariando e rompendo as expectativas daqueles que esperavam uma recriação visual do texto popular.

No conto infantil, o gato de botas caracterizar-se-ia como um legítimo anti-herói em razão dos artifícios pouco lícitos adotados para que seu dono, o filho do moleiro, se tornasse fidalgo. $\mathrm{Na}$ animação, o caráter duvidoso do protagonista é preservado. Seu itinerário em busca dos feijões mágicos que levariam até a gansa que botava ovos de ouro, é marcado por mentiras, embustes e golpes baixos. Na verdade, ele estaria bem mais próximo do mito de Zorro e do estereótipo do homem latino a que do personagem do conto de fadas.

Igualmente inserida no território do anti-herói está Elisabeth Halsey, a protagonista do filme Uma Professora sem Classe (2011). Enquanto Hollywood exaltou em suas histórias as proezas de professores emblemáticos (e que aqui vale citar títulos como Ao Mestre com Carinho (1967), Sociedade dos Poetas Mortos (1989), Mentes Perigosas (1995) e Escritores da Liberdade (2007)), destaca-se aqui a figura deprimente de uma educadora destituída de qualquer compromisso político e pedagógico. A dualidade entre essência e aparência, típica de Ted e do gato de botas, outrossim se faz presente em Uma Professora sem Classe: é uma jovem bela, encantadora e atraente, devidamente interpretada por Cameron Diaz. O uso de drogas e de bebidas, o rancor com que trata os alunos, a perversidade perante os demais docentes e o estímulo torpe para atuar na sala de aula (almejava um bônus para uma intervenção cirúrgica em seus seios, a fim de seduzir determinado professor substituto) garantem a Elisabeth um desvio de caráter tão grave que beira o patético - dado responsável pelo humor durante todo o enredo.

Ademais, é o efeito contrário desse desvio de caráter que reserva à personagem a simpatia por parte do leitor. Como todos os anti-heróis aqui mencionados, não há uma reprovação para a conduta dos mesmos, visto que, pelo exagero que abarcam, abalam os baluartes da moral e edificam uma ética particular, em que os fins justificam os meios. 


\section{The End?}

A discussão a respeito da tipologia de heróis na trajetória do cinema, das animações e da HQ é estimulante, mas não conclusiva. Em maior ou menor grau, está na produção pioneira da primeira metade do século XX e nos títulos contemporâneos, desdobrando-se em diversos gêneros. O herói modelar, por exemplo, já poderia ser visualizado tanto em Ben-Hur, de 1959, como também no Gladiador, de 2000. O mesmo caberia aos excêntricos, detectados em uma galeria de personagens que vão desde Tempos Modernos (1936) até O Auto da Compadecida (2000). Tal categorização de protagonistas, no entanto, compreende uma sugestão para a prática de análise textual. Não se esgotaria, é claro, na projeção dos grupos aqui tratados, tendo em vista a complexidade no processo de composição da personagem. Outro traço da produção contemporânea reside na plurissignificação. São narrativas que, muitas vezes, mantêm-se abertas a plena intervenção do leitor. Exemplo maior dessa questão localiza-se em As aventuras de Pi (2013), cujo desfecho, edificado em meio a duas versões de uma mesma história narrada pelo protagonista epônimo, gera dúvidas e motiva reflexões. A primeira foi alicerçada em uma estrutura metafórica permeada de requinte dramático, ao passo que a segunda, destituída de uma linguagem conotativa, explora as mazelas da alma humana. Ambas revestidas de efeito de veracidade e que clamam do leitor o veredicto final.

Inscrita também nessa poética pós-moderna vigora a intertextualidade, desdobrando-se em seus diversos níveis (citação, paródia, pastiche e carnavalização). As narrativas dialogam com o cinema, a literatura, as animações e os quadrinhos, oferecendo ao destinatário a atualização de histórias já contadas, já codificadas, já exploradas. Formam, assim, uma rede de conexões interdiscursivas, em que os ícones, índices e símbolos são ressignificados a cada nova releitura. Frente a isso, muitos heróis, oriundos da literatura, da mitologia e dos quadrinhos, preservam alguns elementos do contexto em que foram criados para inaugurar, a partir de então, uma nova cronologia, como acontece com Perseu, Conan, Lanterna Verde e o Capitão América. 


\title{
LITERATURE, CINEMA AND MARKET: \\ A STUDY ABOUT THE TYPOLOGY OF HEROES REGISTERED IN CONTEMPORARY CULTURAL PRODUCTION.
}

\begin{abstract}
The present article, which is the result of a larger research about the different profiles of protagonists who populate both literature and cinema, deals with mapping the models of heroes that travel through the contemporary cultural production addressed to young audiences. For this, the theoretical contributions of Campbel (2007) and of critics who turn to the articulations between literature, cinema and cultural industry are taken as reference. Therefore, this article does not intend to analyze one or the other work, but to trace, from a historicist look and also from a look at the protagonist characters' trajectory in different texts and contexts, the multiple faces of the contemporary hero against the various market interests.
\end{abstract}

KEYWORD: Movie theater; Hero; Literature.

\section{REFERÊNCIAS}

BEAUMONT, L. A Bela e a Fera. São Paulo: Scipione, 2000 [primeira edição em 1740].

BOJUNGA, L. Aula de Inglês. Rio de Janeiro: Casa Lygia Bojunga, 2006.

BOWDEN, O. Assassins Creed. Rio de Janeiro: Editora Galera Record, 2011.

BRAZ, E. João e o Pé de Feijão. São Paulo: Larousse Jr., 2003.

BULFINCH, T. O Livro de Ouro da Mitologia: História de Deuses e Heróis. Rio de Janeiro: Ediouro, 2006.

CAMPBELL, J. O Herói de Mil Faces. São Paulo: Pensamento, 2007.

CARROLL, L. Alice no país das Maravilhas. São Paulo: Objetivo, 1990 [primeira edição em 1865]

COELHO, N.N. Literatura Infantil: Teoria, análise e didática. São Paulo: Moderna, 2000.

CORNWELL, B. Rei do Inverno. São Paulo: Editora Record, 2011.

DUMAS, A. El Conde de Montecristo. Barcelona: Akad Ediciones, 2005 [primeira edição em 1844].

ECO, U. O Nome da Rosa. Rio de Janeiro: O Globo, 1984.

ECO, U. Pós-escrito ao Nome da Rosa. Rio de Janeiro: Nova Fronteira, 1985.

ECO, U. Semiótica e Filosofia da Linguagem. São Paulo: Ática, 2011. 
FERREIRA, E. A. G. R. A leitura dialógica como elemento de articulação no interior de uma biblioteca vivida. SOUZA, R. J. Biblioteca escolar e práticas educativas: o mediador em formação. Campinas: Mercado das Letras, 2009.

GOTLIB, N. Teoria do Conto. São Paulo: Ática, 2000.

GRIMM, J. \& W. Contos de Grimm: Rapunzel. São Paulo: Ática, 2002 [primeira edição em 1812].

GRIMM, J. \& W. Contos de Grimm: A Bela Adormecida. São Paulo: Ática, 2002 [primeira edição em 1812]

GRIMM, J. \& W. Contos de Grimm: Chapeuzinho Vermelho. São Paulo: Ática, 2002 [primeira edição em 1812]

HOUCK, C. A Maldição do Tigre. Rio de Janeiro: Editora Arqueiro, 2011.

HUTCHEON, L. Poética do pós-modernismo. Rio de Janeiro: Imago, 1991.

KENYON, N. A Ordem. Rio de Janeiro: Editora Galera Record, 2012.

LAJOLO, M. \& ZILBERMAN, R. Literatura Infantil: História e Histórias. São Paulo: Ática, 1988.

LOBATO, M. Reinações de Narizinho. São Paulo: Brasiliense, 1970.

LOTTERMAN, C. Escrever para armazenar o tempo: morte e arte na obra de Lygia Bojunga. Cascavel: Edunioeste, 2010.

LURKER, M. Dicionário de Simbologia. São Paulo: Martins Fontes, 2003.

MCCUlLEY, J. A Marca do Zorro. São Paulo:Panda Books, 2010 [primeira edição em 1919].

MARTIN, G. Crônicas de Gelo e Fogo. São Paulo: Editora Leya Brasil, 1996.

MORELLI, A. Super-heróis nos desenhos animados. São Paulo: Editora Europa, 2010.

ONDJAKI. AvóDeqanove e o Segredo do Soviético. São Paulo: Cia das Letras, 2009.

PACHECO, E. D. O Pica-pau: herói ou vilão? Representação social da criança e reprodução da ideologia dominante. São Paulo: Editora Loyola, 1985.

REZENDE, S. A mocinha do Mercado Central. São Paulo: Editora Globo, 2011.

SPOHR, E. A Batalha do Apocalipse. Campinas: Verus Editora, 2010.

STIERLE, K. Que significa a recepção de textos ficcionais. LIMA, L. C. A literatura e o leitor: textos de estética da recepção. Rio de Janeiro: Paz e Terra, 1979.

STOKER, B. Drácula. São Paulo: Landmark, 2005 [primeira edição em 1919].

TREVIZAN, Z. O Leitor e o Diálogo dos Signos. São Paulo: Ed. Clíper, 2000. 
TREVIZAN, Z. Contribuições da Semiótica para a Alfabetização do Olhar. In: GERBRAN, R. Contexto Escolar e processo Ensino-Aprendizagem: Ações e Interações. São Paulo: Arte e Ciência Editora, 2004.

Lista de OBRAS citadas: cinema, animação e quadrinhos:

\begin{tabular}{|c|c|c|}
\hline OBRA & GÊENERO & ANO \\
\hline Vampiros & Cinema & 1915 \\
\hline Nosferatu & cinema & 1922 \\
\hline O fantasma da ópera & cinema & 1925 \\
\hline Frankenstein & cinema & 1931 \\
\hline Drácula & cinema & 1931 \\
\hline Batman & HQ & 1932 \\
\hline Tempos modernos & cinema & 1936 \\
\hline ...E o vento levou. & cinema & 1939 \\
\hline O corcunda de Notredame & cinema & 1939 \\
\hline Pica-pau & animação & 1940 \\
\hline Superman & HQ & 1941 \\
\hline Godzila & cinema & 1954 \\
\hline A bela adormecida & animação & 1959 \\
\hline Ben-Hur & cinema & 1959 \\
\hline Capitão América & HQ & 1966 \\
\hline Ao mestre com carinho & cinema & 1967 \\
\hline A fantástica fábrica de chocolate & cinema & 1971 \\
\hline Guerra nas estrelas & cinema & $\begin{array}{l}1977,1980 \mathrm{e} \\
1983 .\end{array}$ \\
\hline Simbá contra o olho do tigre & cinema & 1977 \\
\hline Superman & cinema & 1978 \\
\hline Fúria de titãs & cinema & 1981 \\
\hline Os ursinhos carinhosos & animação & 1981 \\
\hline Conan, o destruidor & cinema & 1982 \\
\hline Rambo & cinema & 1982 \\
\hline Os caça-fantasmas & cinema & 1984 \\
\hline Mestres do universo & animação & 1984 \\
\hline
\end{tabular}




\begin{tabular}{|c|c|c|}
\hline Thundercats & animação & 1985 \\
\hline De volta para o futuro & cinema & 1985 \\
\hline A mosca & cinema & 1986 \\
\hline Mestres do universo & cinema & 1987 \\
\hline A pequena sereia & animação & 1989 \\
\hline Os Simpsons & animação & 1989 \\
\hline Sociedade dos poetas mortos & cinema & 1989 \\
\hline Perfume de mulher & cinema & 1993 \\
\hline O rei leão & animação & 1994 \\
\hline Mentes perigosas & cinema & 1995 \\
\hline Sleepers: a vingança adormecida & cinema & 1998 \\
\hline Matrix & cinema & 1999 \\
\hline O Auto da Compadecida & cinema & 2000 \\
\hline Gladiador & cinema & 2000 \\
\hline Shrek & animação & 2000 \\
\hline Monstros S. $A$. & animação & 2000 \\
\hline O senhor os anéis: a sociedade do anel. & cinema & 2001 \\
\hline Harry Potter e a pedra filosofal & cinema & 2001 \\
\hline Chocolate & cinema & 2001 \\
\hline A vila & cinema & 2004 \\
\hline $\begin{array}{l}\text { Crônicas de Nárnia: o leão, a feiticeira e o armá- } \\
\text { rio }\end{array}$ & cinema & 2005 \\
\hline Madagascar & animação & $\begin{array}{l}2005,2010 \text { e } \\
2012\end{array}$ \\
\hline O código da Vinci & cinema & 2006 \\
\hline Pequena Miss Sunshine & cinema & 2006 \\
\hline O diabo veste prada & cinema & 2006 \\
\hline Escritores da liberdade & cinema & 2007 \\
\hline Batman: o cavaleiro das trevas & cinema & 2008 \\
\hline O menino do pijama listrado & cinema & 2008 \\
\hline Turma da Mônica jovem & $\mathrm{HQ}$ & 2008 \\
\hline Crepúsculo & cinema & 2009 \\
\hline Peirce Jackson e o ladrão de raios & cinema & 2010 \\
\hline Fúria de titãs & cinema & 2010 \\
\hline Alice no país das maravilhas & cinema & 2010 \\
\hline
\end{tabular}




\begin{tabular}{|l|l|l|}
\hline Capitão América & cinema & 2011 \\
\hline Lanterna Verde & cinema & 2011 \\
\hline O espetacular homem-aranha & cinema & 2011 \\
\hline Planeta dos macacos: a origem & cinema & 2011 \\
\hline A garota da capa vermelha & cinema & 2011 \\
\hline Uma professora sem classe & cinema & 2011 \\
\hline Os Smurfs & cinema & 2011 \\
\hline Rio & animação & 2011 \\
\hline Branca de Neve e o caçador & cinema & 2012 \\
\hline Frankenweenie & animação & 2012 \\
\hline O gato de botas & animação & 2012 \\
\hline Ted & cinema & 2012 \\
\hline A invenção de Hugo Cabret & cinema & 2012 \\
\hline As aventuras de Pi & cinema & 2013 \\
\hline
\end{tabular}

Recebido em: 05/04/2018. Aprovado em: 04/08/2018. 